\title{
Gender Difference on Anxiety, Adjustment, Emotional Intelligence, Study Habit and Attitude among Adolescents
}

\author{
Jesna Sivasankar $^{1 *}$, Vidhya Ravindranadan ${ }^{2}$
}

\section{ABSTRACT}

The major purpose of this study is to find out anxiety, adjustment, emotional intelligence, study habits and attitude difference between adolescent boys and girls (14-16years). For this purpose data was collected from 60 high school students; 30 boys and 30 girls. The tools used were State and Trait Anxiety Test (STAT), Academic Anxiety Scale, Global Adjustment Scale, Emotional Intelligence Scale, and Test of Study Habits and Attitudes (TSHA). The results indicate that there is no significant mean difference in general anxiety and academic anxiety between boys and girls. However there are significant gender difference in certain dimensions of Emotional Intelligence like empathy, self-motivation, self-development, Study Habits, attitude, and certain dimensions of adjustment.

Keywords: Gender Difference, Anxiety, Adjustment, Emotional Intelligence, Study habits, Attitude, Adolescence

Anxiety is a prevalent psychological issue among adolescents. It is the apprehension, tension or uneasiness related to expectation of danger whether internal or external. It may be focused on an object, situation or activity that is avoided or may be unfocused (Kendell, et.al, 1992). Many of the anxieties are fairly common and transitory. Their appearance is normal in development. Anxiety is associated with substantial negative effects on children's social, emotional and academic success (Essau, Conradt \& Pertmann, 2000). Anxiety is often undiagnosed due to internalization of its symptoms. It has negative influence not only on academic success but also on emotional and social well being, which affect the coping skill as well as adjustments of self towards life, others and so on.

In Kerala, the emphasis of academic achievement is more irrespective of urban or rural differentiation. The presence of approximately 13000 schools across Kerala can be counted

\footnotetext{
${ }^{1}$ Research Scholar, Research and Development Centre, Bharathiar University, Coimbatore, Tamil Nadu, India

${ }^{2}$ Assistant Professor, Research \& Post Graduate, Dept. of Psychology, Union Christian College, Aluva, Kerala, India

*Responding Author

(C) 2016 J Sivasankar, V Ravindranadan; licensee IJIP. This is an Open Access Research distributed under the terms of the Creative Commons Attribution License (http://creativecommons.org/licenses/by/2.0), which permits unrestricted use, distribution, and reproduction in any Medium, provided the original work is properly cited.
} 


\section{Gender Difference on Anxiety, Adjustment, Emotional Intelligence, Study Habit and Attitude among Adolescents}

among the proof of high relevance on primary academics. The literacy rate of Kerala is also high.

There is excessive pressure among adolescents on academic performance and are expected to achieve greater than their individual capacity especially among the high school students. Among the high school classes, Class $9^{\text {th }}$ and Class $10^{\text {th }}$ have higher pressure as they would be preparing for their Secondary Examinations and its results are vital for higher studies. Entry to higher Secondary is the opening doors towards ones career.

Generally, girls seem to experience anxiety more than boys during adolescence. Adolescent girls report a greater number of worries, more separation anxiety, and higher levels of generalized anxiety (Campbell\& Rapee, 1994). An alternative and possibly related explanation may revolve around socio cultural factors including those that allow girls to admit their fears (Ollendick, Matson and Helsel, 1985). Parents also report more fears in girls than boys because fearful behavior is seen more acceptable in girls (Harris \& Ferrari, 1983). Anxiety has also been linked to parenting practices and features of parent- child relationships (Rapee, 1997).

Factor analyses have yielded further information on the organization of the content of anxiety due to development. The Five Factor structure include: (1). Fear of Failure and Criticism (2.) Fear of Unknown, (3) Fear of Injury and Small Animals, (4). Fear of Danger and Death, and (5) Medical Fears (Ollendick, Matson and Helsel, 1985). In addition to changes in the content of fears, quantitative changes also occur with development. Fear appears to peak between two and half years to four years of age and then start to decline. However older adolescents (16-18) still report and average of 11.6 fears (from a list of 80 potential fears) compared to an average of 14.2 fears in 7 to 9 year- olds (Ollendick, Matson and Helsel, 1985). This demonstrates that the decrease in fears is not as great as expected because earlier fears are replaced by new fears that are associated with particular developmental levels (Kendall and Ronan, 1990).

Anxiety also tends to hamper the emotional stability as well as the adjustment of individuals to his environment. Preliminary investigations have found that approximately $9 \%$ of children diagnosed with overanxious disorder (Last et al., 1987a) or school phobia (Last, Strauss and Francis, 1987) met DSM III criteria for concurrent behaviour disorder, it is possible that the fidgeting and distractibility of the over anxious child can be largely attributed to preoccupation with worries (Kendal, et al, 1992)

Anxiety can be classified into three sections in which academic anxiety is situation-specific form of anxiety related to academic circumstances (Tohill \& Holyoak, 2000). Test anxiety, any particular subject's anxiety, and any type of institutional related anxiety, all are included to academic anxiety (Cassady, 2010). Academic (test) anxiety leads to academic difficulties 


\section{Gender Difference on Anxiety, Adjustment, Emotional Intelligence, Study Habit and Attitude among Adolescents}

through irrelevant thoughts, preoccupation and reduce attention and concentration (Eysenck, 2001). Academic achievement of young pupil is hampered by anxiety (Reilly and Lewis, 1991).

Adjustment is a behavioral process by which a person maintains a balance among various needs that encounters at a given point of time. It is also identified as an achievement too. When the relationship between individual and the environment is in norms, then it is said that adjustment is achieved. Adjustment refers to the adequacy of the personal and interpersonal processes that we use to adapt to our environment. It refers to a process wherein one builds variations in the behavior to achieve harmony with oneself, others or the environment with an aim to maintain the state of equilibrium between individual and the environment. A well adjusted person is someone who engages in behaviors that are appropriate for the culture and a given interpersonal situation. It is the course of behavior; an individual follows in demands of internal, external and social environment. The harmony and conflict within and among one's behavior, value-belief systems, affective reactions, etc works as major determinants of adjustment.

Emotional intelligence (EI) is the ability to carry out accurate reasoning focused on emotions and the ability to use emotions and emotional knowledge to enhance thought. It is the ability to perceive and express emotions, to reason about and use them, and to manage them to foster personal growth (Mayer, Roberts, \& Barsade, 2008; Rivers et al., 2012). This construct is linked to higher social skills and fewer behavior problems in childhood (Mayer et al., 2008), and among older youth, is associated with lower substance use and better academic grades (Parker, et al, 2004). It predicts social relations, workplace performance, and mental and physical well-being.

Study habits are mainly external factors that facilitate the study process such as sound study routines that include how often a student engage in studying sessions, review the material, selfevaluate, rehearse, and studying in a conducive environment (Credé, 2008). Study habits and study attitudes are multi dimensional in nature. That is, effective studying requires not only that the students possess knowledge of appropriate studying techniques and practices (study skills), but also sustained and deliberate effort (study motivation), self-regulation, ability to concentrate, self-monitoring (study habits), and sense of responsibility for and value in one's own learning (study attitude).

Attitude has been long considered as a central concept in social psychology. Allport defined an attitude as "a mental and neural state of readiness, organized through experience, exerting a directive and dynamic influence upon the individual's response to all objects and situations with which it is related." 


\section{Gender Difference on Anxiety, Adjustment, Emotional Intelligence, Study Habit and Attitude among Adolescents}

\section{Objective}

- The objective of the present study is to understand the gender difference on anxiety, adjustment, emotional intelligence, study habits and attitude among adolescent students.

\section{Hypothesis:}

1. There is no gender difference in trait anxiety and state anxiety among adolescent students.

2. There is no gender difference in adjustment among adolescent students.

3. There is no gender difference in academic anxiety among adolescent students.

4. There is no gender difference in emotional intelligence among adolescent students.

5. There is no gender difference in study habits among adolescent students.

6. There is no gender difference in attitude among adolescent students.

\section{METHOD:}

\section{Sample}

The sample of the present study consists 60 high school students, 30 boys and 30 girls belongs to an age group of 14-16 years, studying in Government School, Manghai, Ernakulam District, Kerala.

\section{Materials}

The study tools used for attaining the objectives are:

1. State and Trait Anxiety Test (STAT) by Sanjay Vohra is based upon MAP series that measures 20 personality dimensions. Separate scores measuring Trait and State Anxiety may also be derived apart from total anxiety score. The test includes 40 anxiety items that measures five dimensions of anxiety. They are (1) Guilt Proneness (Gp): a person with high score on the dimension tends to be depressed, apprehensive, troubled, mood, a worrier, full of foreboding and brooding. He has a child like tendency $t$ anxiety in difficulties and does not feel accepted and or free to participate in groups. Low score on dimension Gp tends to be self assured, confident, serene, and placid with unshakable nerve. He has a mature, un anxious confidence in himself and his capacity to deal with things. (2) Tension (Tn): the individual who scores high on Tn tends to be very tense, excitable, frustrated driven, restless, fretful and impatient. Often fatigued, the person is unable to remain inactive and it is often seen that high tension level disrupt school and work performance. The person who scores low on Tn tends to be sedate, relaxed, tranquil, composed and satisfied. (3) Maturity (Ma): the person scoring high on this dimension is easily affected by feelings and tends to be low in frustration tolerance, changeable and plastic. He evades necessary realty demands and is neurotically fatigued. Easily annoyed and emotion may show symptoms like phobias, sleep disturbances, psychosomatic complaints etc. The person scoring low on Ma is emotionally stable faces reality and calm. He tends to e emotionally mature, stable and realistic about life and is able to maintain solid group morale. (4) Suspiciousness $(\mathrm{Su})$ : the person who scores high on $\mathrm{SU}$ tends to be suspicious, mistrusting, 


\section{Gender Difference on Anxiety, Adjustment, Emotional Intelligence, Study Habit and Attitude among Adolescents}

doubtful and hard to fool. He is often involved in his own ego and is self opinionated and is unconcerned about other people. Hence is a poor team member the person scoring low on dimension Su tends to be trusting, free of jealous tendencies, adaptable, cheerful, and concerned about other people and is a good team worker. Self Control (Sc): the person scoring high on dimension Sc will not be bothered with will control and regard for social demands. He is careless of protocol and follows own urges. Not overly considerate, careful or painstaking and can be maladjusted. The person scoring low on dimension Sc tends to have strong control of his emotions and general behaviour. He is inclined to be socially aware and careful and gives evidence of what is commonly termed "self- respect" and regard for social reputation.

2. Academic Anxiety Scale developed by A. K Singh \& Dr. A. Sen Gupta has been developed for use with the school students of class VII, IX and X (age range: 13-16 years). The percentile scores have been prepared for both Rural and Urban students and qualitatively interprets anxiety as High, Average and Low Academic Anxiety. The scale is a satisfactory tool for assessing academic anxiety among children and it can be applied for further research and investigation.

3. Emotional Intelligence Scale by Anukool Hyde, Sanjyot Pethe, Upinder Dhar assess ten factors like (1) Self awareness which is being aware of oneself. (2) Empathy which is the feeling and understanding of other person (3). Self motivation is being motivated internally (4). Emotional Stability (5) Managing Relations (6) Integrity (7) Self Development 8) Value Orientation (9) Commitment (10) Altruistic behaviour. The raw score is interpreted as High, Normal and Low as per the distinctions of scores given in the manual.

4. Global Adjustment Scale-Student form (GAS-S) developed by Sanjay Vohra for assessing students between age ranges 13 to 19 years. The student form tries to obtain reliable data from the student concerning what he thinks and feels about his Family relationship, health, his social environment, emotions, school and sex related behaviour. The dimensions that are assessed by the test are: (1) emotional adjustment (Em): high scores on Em suggests the student is highly sensitive and has concerns in areas like the tendency to day dream and imagine things, lively and unstable feelings of fear, anger and excitement, feelings of depression coming from isolation and inferiority, guilt and self- consciousness, easily hurt feeling and frequent episodes of worry, anxiety and nervousness. (2). Family Adjustment (Fm): High scores on Fm tends to associate with conflicts resulting due to the inability to live up to the expectations of one or both parents/ siblings, feelings of parental/ sibling rejection, persistent tensions in the family, arbitrary restrictions and no- affectionate disciplining, sibling rivalries, inability to identify with or relate to one or both parents, divorce or separation in the family, possessive parents, lack of freedom for expression. (3) Health Adjustment (He): Extremely high scores on He reflects a history of poor health difficulties or an excessive pre occupation with his body mentally, or both. Many common health problems faced by students are frequent cold and throat problems, diseases, operation or accidents with residual effects, fatigue, sleeplessness, weight problems, and history of absence from school die to illness etc. There is high inter correlation between $\mathrm{He}$ and Em, which suggest that there may be tendency for students with the health problems to experience 


\section{Gender Difference on Anxiety, Adjustment, Emotional Intelligence, Study Habit and Attitude among Adolescents}

tensions in their social and emotional relationships with others. (4). School Adjustment ( $\mathrm{Sc}$ ): During schooling phase, students learn about the stresses and hazards in school. Some of the common stressors are: sudden demands for new kind of performance, rapid obsolescence of knowledge and skills, increased demands for specialty, likelihood of transfer. (5). Sexual Adjustment (Se): covers major areas like interest in sexual relationships, sexual anxiety, and guilt associated sexual activity, permissiveness or openness to sexual activities. (6) Social adjustment (So): high scorers show attitudes and behaviours to other people where they have a feel that people in general are stupid, dull, bore some and irrational, they believe that one cannot afford to trust people even friends, they feel that people are unfriendly and that they don't understand the individual. They also do not hesitate to criticize people openly and they believe that altruism is basically selfish and that good deeds are useless.

5. Test of Study Habits and Attitudes (TSHA) by Dr. C. P. Mathur is based on nine areas of study techniques, habits and attitudes viz., Attitude towards teachers; home environment; Attitude towards education; Study Habits; Mental Conflict; Concentration; Home Assignment; Self Confidence; Examination.

\section{RESULT AND DISCUSSION}

The present study intends to find out the gender difference on Anxiety, Adjustment, Emotional Intelligence, Study Habit and Attitude.

In order to find out gender difference ' $t$ ' test has been conducted and the results are given below.

Table 1: Comparison between Boys and Girls on Academic Anxiety

\begin{tabular}{|c|c|c|c|c|c|}
\hline Variable & gender & $\mathbf{N}$ & Mean & Std. Deviation & t-value \\
\hline \multirow{2}{*}{ Academic Anxiety } & Male & 30 & 10.57 & 2.555 & \multirow[b]{2}{*}{0.901} \\
\hline & Female & 30 & 11.27 & 3.403 & \\
\hline
\end{tabular}

From the above table it can be inferred that the 't'value is 0.90 ; which is not statistically significant i.e. there is no gender difference on Academic Anxiety among the adolescent students. This may be because of gender equality existing in the academic area. All the students might be experiencing more or less same level of academic anxiety due to the equality in demands on academics irrespective of gender.

Table 2: Comparison between Boys and Girls on State and Trait Anxiety

\begin{tabular}{|c|c|c|l|l|l|l|}
\hline \multicolumn{2}{|c|}{ State and Trait Anxiety } & gender & $\mathbf{N}$ & Mean & Std. Deviation & t-value \\
\hline \multirow{4}{*}{ Guilt Prone(Gp) } & \multirow{2}{*}{ Trait } & Male & 30 & 5.20 & 2.511 & \multirow{2}{*}{0.06} \\
\cline { 3 - 7 } & & Female & 30 & 5.17 & 1.683 & \\
\cline { 3 - 7 } & \multirow{2}{*}{ State } & Male & 30 & 4.80 & 2.074 & \multirow{2}{*}{1.59} \\
\cline { 3 - 7 } & & Female & 30 & 4.03 & 1.629 & \\
\hline
\end{tabular}

(c) The International Journal of Indian Psychology, ISSN 2348-5396 (e)| ISSN: 2349-3429 (p) | 95 
Gender Difference on Anxiety, Adjustment, Emotional Intelligence, Study Habit and Attitude among Adolescents

\begin{tabular}{|c|c|c|c|c|c|c|}
\hline \multicolumn{2}{|c|}{ State and Trait Anxiety } & gender & $\mathbf{N}$ & Mean & Std. Deviation & t-value \\
\hline & \multirow{2}{*}{ Total } & Male & 30 & 10.00 & 3.648 & \multirow{2}{*}{0.91} \\
\hline & & Female & 30 & 9.27 & 2.477 & \\
\hline \multirow{6}{*}{ Maturity (Ma) } & \multirow{2}{*}{ Trait } & Male & 30 & 2.80 & 1.627 & \multirow{2}{*}{1.08} \\
\hline & & Female & 30 & 3.23 & 1.478 & \\
\hline & \multirow{2}{*}{ State } & Male & 30 & 2.83 & 1.663 & \multirow{2}{*}{0.49} \\
\hline & & Female & 30 & 3.07 & 1.946 & \\
\hline & \multirow{2}{*}{ Total } & Male & 30 & 5.63 & 2.526 & \multirow{2}{*}{0.84} \\
\hline & & Female & 30 & 6.20 & 2.670 & \\
\hline \multirow{6}{*}{ Self Control (Sc) } & \multirow{2}{*}{ Trait } & Male & 30 & 2.93 & 2.016 & \multirow{2}{*}{0.133} \\
\hline & & Female & 30 & 3.00 & 1.857 & \\
\hline & \multirow{2}{*}{ State } & Male & 30 & 2.90 & 1.954 & \multirow{2}{*}{3.393} \\
\hline & & Female & 30 & 3.07 & 1.258 & \\
\hline & \multirow{2}{*}{ Total } & Male & 30 & 5.83 & 2.984 & \multirow{2}{*}{0.045} \\
\hline & & Female & 30 & 5.87 & 2.738 & \\
\hline \multirow{6}{*}{$\begin{array}{l}\text { Suspiciousness } \\
(\mathrm{Su})\end{array}$} & \multirow{2}{*}{ Trait } & Male & 30 & 2.53 & 1.592 & \multirow{2}{*}{0.664} \\
\hline & & Female & 30 & 2.87 & 2.240 & \\
\hline & \multirow{2}{*}{ State } & Male & 30 & 2.70 & 2.054 & \multirow{2}{*}{0.464} \\
\hline & & Female & 30 & 2.93 & 1.837 & \\
\hline & \multirow{2}{*}{ Total } & Male & 30 & 5.23 & 2.956 & \multirow{2}{*}{0.484} \\
\hline & & Female & 30 & 5.60 & 2.908 & \\
\hline \multirow{6}{*}{ Tension (Tn) } & \multirow{2}{*}{ Trait } & Male & 30 & 3.37 & 1.671 & \multirow{2}{*}{0.397} \\
\hline & & Female & 30 & 3.53 & 1.737 & \\
\hline & \multirow{2}{*}{ State } & Male & 30 & 3.70 & 1.664 & \multirow{2}{*}{0.312} \\
\hline & & Female & 30 & 3.83 & 1.642 & \\
\hline & Total & Male & 30 & 7.07 & 2.753 & 0405 \\
\hline & 10tal & Female & 30 & 7.37 & 2.977 & 0.403 \\
\hline TOTAI TRAIT & & Male & 30 & 11.63 & 3.700 & 0007 \\
\hline 1UIAL 1 RAII & & Female & 30 & 12.63 & 4.064 & 0.991 \\
\hline ТОТАІ СТАТГ & & Male & 30 & 12.13 & 4.249 & 0760 \\
\hline 1U1ALSIAIE & & Female & 30 & 12.90 & 3.478 & 0.100 \\
\hline ТОТА С С०РГ & & Male & 30 & 23.77 & 6.350 & $112+2$ \\
\hline 101 AL SCURE & & Female & 30 & 25.53 & 5.704 & 1.134 \\
\hline
\end{tabular}

It can be inferred from table 2 that the ' $t$ ' value of anxiety is not statistically significant with relation to the gender. This can be due to the social condition in Kerala where both males and females are considered equally competitive and equal chances for attaining education and favorable social acceptance with respect to opportunities for growth. 


\section{Gender Difference on Anxiety, Adjustment, Emotional Intelligence, Study Habit and Attitude among Adolescents}

The research conducted earlier by Abha Subba Rao (2016) on Academic Stress and Adolescent Distress among the adolescents in Chennai about adolescent anxiety. In one study equal number of male and female college fresh men in city of Bhuvaneshwar found that the male students scored higher on scale of manifest anxiety than female students (Singh \& Singh, 1989). Another study measures manifest anxiety in a sample of Class XI and Class XII in Karnataka and consistent with anxiety literature, female students scored higher than, males (Zareena, Khan, Phadnis, 1988).

The study conducted by A. K.Choudhary and Deepika Jain on anxiety among male and female adolescents shows higher range of anxiety among male adolescents than female adolescents. The authors stress the competition and confusion in taking up decision increasing the anxiety level in male adolescents.

Table 3: Comparison of gender difference on Emotional Intelligence

\begin{tabular}{|c|c|c|c|c|c|}
\hline Emotional Intelligence & Gender & $\mathbf{N}$ & Mean & $\begin{array}{l}\text { Std. } \\
\text { Deviation }\end{array}$ & t-value \\
\hline \multirow[t]{2}{*}{ Self Awareness } & Male & 30 & 16.77 & 2.012 & \multirow[t]{2}{*}{0.790} \\
\hline & Female & 30 & 16.03 & 4.657 & \\
\hline \multirow[t]{2}{*}{ Empathy } & Male & 30 & 19.10 & 2.881 & \multirow[t]{2}{*}{$2.672^{* *}$} \\
\hline & Female & 30 & 16.30 & 4.963 & \\
\hline \multirow[t]{2}{*}{ Self- Motivation } & Male & 30 & 23.40 & 3.645 & \multirow[t]{2}{*}{$4.31 * *$} \\
\hline & Female & 30 & 18.20 & 5.530 & \\
\hline \multirow[t]{2}{*}{ Emotional Stability } & Male & 30 & 14.87 & 3.048 & \multirow[t]{2}{*}{0.000} \\
\hline & Female & 30 & 14.87 & 2.474 & \\
\hline \multirow[t]{2}{*}{ Managing Relations } & Male & 30 & 14.37 & 2.566 & \multirow[t]{2}{*}{0.393} \\
\hline & Female & 30 & 14.70 & 3.870 & \\
\hline \multirow[t]{2}{*}{ Integrity } & Male & 30 & 10.83 & 3.075 & \multirow[t]{2}{*}{0.272} \\
\hline & Female & 30 & 11.07 & 3.552 & \\
\hline \multirow[t]{2}{*}{ Self Development } & Male & 30 & 8.10 & 1.863 & \multirow[t]{2}{*}{$2.146^{*}$} \\
\hline & Female & 30 & 9.50 & 3.048 & \\
\hline \multirow[t]{2}{*}{ Value Orientation } & Male & 30 & 7.73 & 1.507 & \multirow[t]{2}{*}{0.157} \\
\hline & Female & 30 & 7.67 & 1.768 & \\
\hline \multirow[t]{2}{*}{ Commitment } & Male & 30 & 7.93 & 1.388 & \multirow[t]{2}{*}{0.343} \\
\hline & Female & 30 & 8.07 & 1.617 & \\
\hline \multirow[t]{2}{*}{ Altruistic Behavior } & Male & 30 & 7.10 & 1.423 & \multirow[t]{2}{*}{0.62} \\
\hline & Female & 30 & 7.33 & 1.493 & \\
\hline \multirow{2}{*}{$\begin{array}{l}\text { Total Emotional } \\
\text { Intelligence }\end{array}$} & Male & 30 & 130.07 & 11.298 & \multirow[t]{2}{*}{1.708} \\
\hline & Female & 30 & 123.60 & 17.391 & \\
\hline
\end{tabular}

There is no significant difference in dimensions like self- awareness, emotional stability, managing relations, integrity, value orientation, commitment, altruistic behavior among 


\section{Gender Difference on Anxiety, Adjustment, Emotional Intelligence, Study Habit and Attitude among Adolescents}

adolescent boys and girls. This can be attributed to equal chances and gender equality that exist in the educational system of Kerala. Moreover the chances for interaction contributes to the dimensions like self- awareness, emotional stability, managing relations, integrity, value orientation, commitment, and altruistic behavior. However, the mean value of empathy indicates significance at 0.01 level or mean difference is highly significant (t-value 2.672). The mean score indicates that male students have high level of empathy compared to female counterparts. The dimension of self- motivation also exhibits significance at 0.01 level (t-value 4.321). The mean difference is highly significant. The dimension of self- development indicates significance at .05 level (t-value 2.146). This indicates that boys have better self- development than the girls. Significant mean difference in self development ( $t$ - value 2.146) also indicates that gender difference exist in this dimension of emotional intelligence, with a significantly better score among girls. This may be due to the hardworking nature of girls comparatively.

The studies conducted on Gender Differences in Emotional Intelligence among Adolescents of Chandigarh by Katyal and E. Aswathi (2005) shows girls having higher emotional intelligence than boys of same age. However the same study says that higher emotional intelligence for boys is a better predictor for achievement. Better empathy and self motivation and interest for selfdevelopment may be due to the peer influence and better opportunity for socialization outside home for boys than girls. Boys get chances to have more communication with males of other age group (secondary groups) that would enhance better self- motivation and empathy.

Table 4: Comparison of gender difference on Study Habit and Attitude

\begin{tabular}{|l|l|l|l|l|l|}
\hline Variable & gender & N & Mean & $\begin{array}{l}\text { Std. } \\
\text { Deviation }\end{array}$ & t-value \\
\hline Study habit\& Attitude & Male & 30 & 28.53 & 8.068 & $2.396^{*}$ \\
\hline & Female & 30 & 34.03 & 9.640 & \\
\hline
\end{tabular}

The scores indicate there is significant mean difference between the group scores at 0.05 level ( $t$ value 2.396). Girls have better attitude towards studies and habits than boys. A high score of girls on this test indicates high order of good study habits and proper attitudes comparatively with boys.

Table 5: Comparison of gender difference on Adjustment

\begin{tabular}{|l|c|c|c|l|l|}
\hline Global Adjustment Scale & gender & $\mathbf{N}$ & Mean & Std. Deviation & t-value \\
\hline \multirow{2}{*}{ Emotional Adjustment (Em) } & Male & 30 & 18.57 & 4.869 & \multirow{2}{*}{0.456} \\
\cline { 2 - 6 } & Female & 30 & 19.23 & 6.361 & \multirow{2}{*}{$2.248^{*}$} \\
\hline \multirow{2}{*}{ Family adjustment(Fm) } & Male & 30 & 10.53 & 4.547 & \\
\cline { 2 - 6 } & Female & 30 & 13.03 & 4.056 & \\
\hline
\end{tabular}

(c) The International Journal of Indian Psychology, ISSN 2348-5396 (e)| ISSN: 2349-3429 (p) | 98 
Gender Difference on Anxiety, Adjustment, Emotional Intelligence, Study Habit and Attitude among Adolescents

\begin{tabular}{|c|c|c|c|c|c|}
\hline Global Adjustment Scale & gender & $\mathbf{N}$ & Mean & Std. Deviation & t-value \\
\hline \multirow{2}{*}{ Health Adjustment (Hm) } & Male & 30 & 14.40 & 5.143 & \multirow{2}{*}{0.717} \\
\hline & Female & 30 & 13.50 & 4.562 & \\
\hline \multirow{2}{*}{ School Adjustment (Sc) } & Male & 30 & 11.50 & 3.589 & \multirow{2}{*}{1.394} \\
\hline & Female & 30 & 12.83 & 3.815 & \\
\hline \multirow{2}{*}{ Sexual Adjustment (Se) } & Male & 30 & 15.27 & 4.578 & \multirow{2}{*}{1.17} \\
\hline & Female & 30 & 13.83 & 4.871 & \\
\hline \multirow{2}{*}{ Social Adjustment (So) } & Male & 30 & 24.83 & 4.202 & \multirow{2}{*}{$2.27 *$} \\
\hline & Female & 30 & 22.00 & 5.388 & \\
\hline
\end{tabular}

The adjustment score indicates that there is no significant difference in dimensions like emotional adjustment, health adjustment, school adjustment, sexual adjustment between boys and girls. However there is 0.05 level significance in family adjustment (t-value 2.248) and in social adjustment (t-value 2.27). It is interesting to note that high level of family adjustment can be seen among girls and high level of social adjustment among boys.

The result of research by Vishal and Kaji (2014) on adjustment of adolescent boys and girls in Ahmadabad related to the present result that there is significant difference in home, social and emotional adjustment. But there is not much difference in school adjustment between boys and girls.

\section{CONCLUSION}

The major findings of the study as follows:

1. There is no significant gender difference in academic anxiety.

2. There is no significant gender difference in state and trait anxiety and its dimensions.

3. There is significant gender difference in the sub dimensions of emotional intelligence like, empathy, self-motivation and self-development and no significant gender difference between self awareness, emotional stability, managing relations, integrity, value orientation, commitment, altruistic behaviour.

4. There is significant gender difference in study habits and attitude between boys and girls.

5. There is significant gender difference in dimensions of adjustment like family adjustment and social adjustment and no significant gender difference in emotional adjustment, Health adjustment, school adjustment, and sexual adjustment.

\section{Acknowledgments}

The author appreciates all those who participated in the study and helped to facilitate the research process.

\section{Conflict of Interests}

The author declared no conflict of interests. 


\section{Gender Difference on Anxiety, Adjustment, Emotional Intelligence, Study Habit and Attitude among Adolescents}

\section{REFERENCE}

Anukool, H., Sanjyot, P., Upinder, D., (2005), Emotional Intelligence Scale-HPD, National Psychological Corporation.

Aquino, L. B., (2011), Study Habits and Attitudes of Freshmen Students: Implications for Academic Intervention Programs, Journal of Language Teaching and Research, ISSN: 1798-4769,Vol. 2, No. 5, (pp. 1116-1121),

Credé, M. A. (2008). The Third Pillar Supporting Collegiate Academic Performance. Perspectives on Psychological Science, 3(6), 425-453.

Campbell, M. A .\& Rapee, R. M. (1994). The nature of feared outcome representations in children. Journal of Abnormal Child Psychology, 22(1), 99-111.

Cassady, J. C. (Ed.). (2010). Anxiety in the schools: The causes, consequences, and solutions for academic anxieties. New York, NY: Peter Lang.

Das, S, K., Halder, U. K., Misra, B., (2014) A study on academic anxiety and academic achievement on secondary level school students, International Multi Disciplinary Research Journal, Vol:4, Issue. ISSN NO:2230-7850.

Essau, C. A., Conradt, J., Petermann, F. (2000). Frequency, comorbidity and psychosocial impairment of anxiety disorders in German adolescents. Journal of Anxiety Disorders, $14,263-279$

Eysenck, M.W. (2001). Principles of cognitive psychology. Hove, East Sussex: Psychology Press

Feldman, R. S.(2011) Understanding Psychology, (10th Edition). (pp 285-286) Tata McGrawHill Edition.

Harris \& Ferrari, 1983- Harris , S.L., \& Ferrari. M( 1983), Developmental Factors in Child Behavior Therapy. Behaviour therapy, 14, 54-72

Katyal, S., \& Aswathi, E., (2005) Gender difference in emotional intelligence among adolescents of Chandigarh, J. Hum. Ecol., 17(2): 153-155

Kendall, Chansky, Ronan, Allyn, \& Bacon, (1992), Anxiety disorders in Youth -Cognitive Behaviour Interventions, Needham Heights, Allyn, M.A \& Bacon. Nirmala, D., A study of adjustment of students in relation to personality and achievement motivation, Bhartiyam International Journal of Education and Research, Vol:1, Issue 12011 ISSN

Kendall, P.C, \& Ronan, K.R, (1990). Assessment of Children's anxieties, fears and phobias: Cognitive Behaviour Models and methods. In C.R. Reynolds \& .Kamphaus, K.A (Eds), Handbook of Psychological and Educational Assessment in Children (pp223-244), New York: Guilford Press

Last, C.G, Strauss, C.C., \& Francis, G., (1987). Comorbidity among childhood anxiety disorders. Journal of Nervous and Mental Disease, 175, 726-730

Last, C.G., Hersen, M., Kazdin, A.E., Finkelstein, R., \& Strauss, C.C., (1987), Comparison of DSM- III separation anxiety and overanxious disorders: Demographic characteristics and 


\section{Gender Difference on Anxiety, Adjustment, Emotional Intelligence, Study Habit and Attitude among Adolescents}

patterns of comorbidity, Journal of American Academy of Child and Adolescent Psychiatry, 26, 527-531

Mayer, J. D., Roberts, D. R., Barsade, S. C., (2008), Human Abilities: Emotional intelligence, annual review of psychology, http://psych.annualreviews.org

Mathur, C.P., Dr, Test of Study Habits and Attitudes, National Psychological Corporation

Norbert, S., Gred, B., Construction of attitudes, Manuscript from "Intrapersonal processes (Blackwell handbook of social psychology) (pp. 436-457), Oxford, UK: Blackwell,.

Ollendick, T. H., Matson, J. L., \& Helsel, W. J.(1985). Fears in children and adolescents: Normative data. Behaviour Research and Therapy, 23, 465-467

Parker, J. D. A., Creque, R. E., Barnhart, D. L., Harris, J. A., Majeski, S. A., \& Wood, L. M. (2004). Academic achievement in high school: does emotional intelligence matter? Personality and Individual Differences, 37, 1321-1330.

Rapee, R.M. (1997). Potential role of childrearing practices in the development of anxiety and depression. Clinical Psychology Review, 17,47-68.

Reilly, R.R. and Lewis, E.L. (1991). Educational psychology, NewYork: Laural Tanner Macmillan Company Inc.

Sanjay, V., (2013) Global Adjustment Scale (student form), Psy-com Services,.

Singh, A. K., Sen. A. G., (2005), Academic Anxiety Scale for children, , National Psychological Corporation

Sanjay, V., (2001), State-Trait Anxiety Test, Psy-Com Services.

Subba, R. A., (2016), Academic Stress and Adolescent Distress: the Experience of 12th Standard Students in Chennai, University of Arizona, http://hdl.handle.net/10150/194424 .

Tohill, J. M., \& Holyoak, K. J. (2000). The impact of anxiety on analogical reasoning. Thinking and Reasoning, 6(1), 27-40.

Trinidad, D.R, Johnson C.A. (2002). The association between emotional intelligence and early adolescent tobacco and alcohol use, Personality and Individual Differences. 32:95-105

Vishal, P., Kaji, S. M., (2014), Adjustment of boys and girls school level adjustment in Ahamedabad, International journal of Indian Psychology, Vol: 2, Issue,1.

Zareena, A. Z., Khan, F. B., Phadnis, L. (1988). Anxiety among adolescents. Indian Journal of Behavior, 12, 19-27.

How to cite this article: J Sivasankar, V Ravindranadan (2016), Gender Difference on Anxiety, Adjustment, Emotional Intelligence, Study Habit and Attitude among Adolescents, International Journal of Indian Psychology, Volume 4, Issue 1, No. 79, ISSN:2348-5396 (e), ISSN:2349-3429 (p), DIP:18.01.090/20160304, ISBN:978-1-365-56745-2 